\title{
Blood metabolic profile of broiler chickens fed diets with different types and levels of inulin ${ }^{12)}$
}

\author{
EDYTA KOWALCZUK-VASILEV, EUGENIUSZ R. GRELA, WIOLETA SAMOLIŃSKA, \\ RENATA KLEBANIUK, BOŻENA KICZOROWSKA, ROBERT KRUSIŃSKI, \\ ANNA WINIARSKA-MIECZAN, KATARZYNA KĘPKA, MAŁGORZATA KWIECIEŃ
}

Institute of Animal Nutrition and Bromatology, University of Life Sciences, Akademicka 13, 20-950 Lublin, Poland

\author{
Kowalczuk-Vasilev E., Grela E. R., Samolińska W., Klebaniuk R., Kiczorowska B., \\ Krusiński R., Winiarska-Mieczan A., Kępka K., Kwiecień M. \\ Blood metabolic profile of broiler chickens fed diets with different types and levels of inulin
}

Summary

The study was performed to evaluate the effect of a dietary level of two types of inulin differing in the degree of polymerization (DP), supplemented at different levels, on selected metabolic and immunological parameters of broiler chicken blood. Two hundred and forty 1-day-old broiler chickens were fed a diet without inulin addition (control group, C) or with standard inulin from chicory root with DP $\geq 10$ (SI) or long-chain inulin (LCI) of DP $\geq 23$ (Inulin Orafti ${ }^{\circledR}$ GR or Inulin Orafti ${ }^{\circledR}$ HPX, respectively; Orafti Beneo GmbH, Mannheim, Germany) at a level of $0.2 \%, 0.4 \%$, or $0.6 \%$. Therefore, 7 dietary treatments were formed. The experiment was carried out for 6 weeks. The addition of inulin had a significant $(p \leq 0.05)$ impact on the blood parameters analyzed, especially on the protein and lipid profile. The degree of polymerization of inulin and its level in the diet significantly affected the content of glucose and uric acid and creatinine levels in the blood plasma of 21-day-old chickens. The addition of the different types (SI vs. LCI) and levels (0.2, 0.4, and 0.6) of inulin to the diet and the interaction of these factors affected the total protein level and the content of albumins and globulins. Some differences $(p \leq 0.05)$ were found between the experimental groups in total cholesterol and its HDL fraction content as well as in the activity of ALT and LDH. The other biochemical indices were not affected by the experimental factors. In conclusion, it may be stated that inulin with the higher polymerization degree (LCI; DP $\geq 23$ ) provided better results of the blood metabolic profile throughout the broiler fattening period. However, the impact of this factor is not explicit. The addition of the inulin extract at an amount of 4-6 g per $\mathrm{kg}$ of mixture is recommended, but further experiments are recommended.

Keywords: broiler chickens, prebiotic, inulin, blood

The beneficial effects of prebiotics, nondigestible feed ingredients such as oligosaccharides and inulin, on the host organism result from their selective stimulation of the growth and/or activity of gut microbiota, primarily from the genus Bifidobacterium and the Lactobacillus species. Thus, the use of prebiotics in animal diets is expected to be advantageous due to their indirect positive influence on both the growth and the health of animals $(8,42)$.

Inulin, extracted from chicory (Cichorium intybus), consists of one terminal $\alpha$-glucose molecule and a variable number of $\beta$-fructose moieties exclusively linked by $\beta(2 \rightarrow 1)$ glycosidic bonds (47). It is a mixture of

This research was supported in part by project No. 12006710 from the National Centre for Research and Development (NCBiR).

2) Praca zaprezentowana na XLVI Sesji Naukowej Sekcji Żywienia Zwierząt Komitetu Nauk Zootechnicznych i Akwakultury Polskiej Akademii Nauk, Lublin, 21-23.06.2017 r. oligomers and linear fructose polymers containing molecules with a degree of polymerization (DP) from 2 to ca. 65 , with an average of $10-12$ units $(14,22)$. The molecule length affects the technological and prebiotic properties of inulin (49) and depends on the source and extraction processes (33). The differences in the polymerization degree between fructans may affect not only their physicochemical and technological properties, but also their biological traits (37). Fructans with DP lower than 10 are known as oligofructose or FOS. Inulin, therefore, contains both oligosaccharides and polysaccharides. Thanks to the $\beta(2 \rightarrow 1)$ glycosidic bond, it resists the breakdown by the host-derived digestive enzymes in the small intestine but is degraded by microbiota, mainly in the large intestine. Inulin-type fructans are believed to modulate the composition of microbiota by enhancing the growth of health-promoting bacteria and suppressing the growth of poten- 
tially pathogenic bacteria. Their activity may influence metabolism and productive results and improve the health status of animals. Inulin, stimulating intestinal bacteria, can support animal performance and health by influencing nutrient digestion, gut microflora, and gut morphology, thus improving the performance of birds (32). However, the mechanisms by which these effects develop are still unclear. Supplementation of inulin or oligofructose to broilers was reported to result in significantly improved performance, particularly in female broilers, due to an increased absorptive capacity of the chicken gastrointestinal tract caused by the increased length of both the small intestine and the colon $(26,55)$. Additionally, positive changes were observed in the intestinal microbiota biocenosis in broilers $(24$, 32 ), although there are also some studies indicating no effect of inulin on the intestinal microbiome (4, 5). Some studies on birds found a decrease in body fat deposition, abdominal fat, and serum cholesterol concentration $(29,45,55)$, and a modified hepatic metabolism of lipids $(29,45)$. However, the differences in results may depend on the composition of the basal diet, inclusion level, type of fructan, adaptation period, and experimental hygienic conditions. The results reported by Sevane et al. (41) revealed a number of genes, processes, and pathways with putative involvement in chicken growth and performance, while reinforcing the immune status of animals and fostering the production of long-chain fatty acids in broilers supplemented with $5 \mathrm{~g}$ of inulin $\mathrm{kg}^{-1}$ diet. They highlighted the functional significance and importance of inulin supplementation as a possible and useful alternative to the use of antibiotics for improving animal production and general immunity in poultry farming, along with a healthier meat lipid profile. The authors indicated major changes in the transcription of a number of genes implicated in the development and maintenance of different tissues, particularly the muscle and nervous systems, fatty acid and protein metabolism, the immune system, gene transcription, cell development, and the maintenance of processes in the liver.

An important factor in the efficacy of feed additives in animal nutrition is the course of metabolic processes, which is manifested in, among others, changes in the values of biochemical and hematological markers. Therefore, the study was performed to evaluate the effect of the dietary level of two types of inulin differing in the degree of polymerization (DP), supplemented at a level of $0.2 \%, 0.4 \%$, or $0.6 \%$, on selected metabolic and immunological parameters of broiler chicken blood.

\section{Material and methods}

Experiment design. The experiment was carried out after receiving approval from the Second Local Ethics Committee at the University of Life Sciences in Lublin (No. 31/2010). Two hundred and forty 1-day-old broiler chickens (Ross 308, Aviagen, Kraków, Małopolska Voivodeship, Poland) were randomly assigned to 7 dietary treatments and placed in 5 cages per treatment, with 4 females and 4 males per cage. The experiment was carried out for 6 weeks. The broiler chickens were fed 2 types of isoprotein and isoenergetic diets: starter (0 to 21 days) and grower (22 to 42 days) as recommended by NŻD (56) (Tab. 1). The birds were fed a diet without inulin addition (control group, C) or with standard inulin from chicory root with DP $\geq 10$ (SI) or long-chain inulin (LCI) of DP $\geq 23$ (Inulin Orafti ${ }^{\circledR} \mathrm{GR}$ or Inulin Orafti ${ }^{\circledR} \mathrm{HPX}$, respectively; Orafti Beneo $\mathrm{GmbH}$, Mannheim, Germany) at a level of $0.2 \%, 0.4 \%$, or $0.6 \%$.

The broiler chickens were reared in $1-\mathrm{m}^{2}$ cages, placed in a room with controlled temperature and humidity, and provided with continuous access to feed and water. The lighting scheme in the hen house made it possible to control the length of light exposure during the day, according to the guidelines on rearing broiler chickens (3).

Blood analysis. At the age of 21 and 42 days, chicks (2 broiler chickens/cage) selected randomly for blood sampling were not given any feed but provided with continuous access to water. Blood was sampled from the ulnar vein (vena cutanea ulnaris) in the morning. Blood samples for analysis were collected in tubes with an anticoagulant, and whole blood was analyzed within three hours of sampling. Plasma for the analysis of the biochemical parameters was obtained by centrifugation of whole blood at $3000 \mathrm{rpm}(603 \times \mathrm{g})$ for $10 \mathrm{~min}$ in a laboratory centrifuge (MPW-350R, MPW Medical Instruments, Warsaw, Poland) at a temperature of $4^{\circ} \mathrm{C}$.

Plasma without signs of hemolysis was analyzed for the content of total protein, albumin, globulin, glucose, uric acid, creatinine, bilirubin, total cholesterol, high-densitylipoprotein cholesterol fraction (HDL-Chol), and triacylglycerols. Low-density lipoprotein cholesterol (LDL-Chol) content was estimated according to the Friedewald et al. (7) equation. The activity of indicator enzymes, i.e. aspartate aminotransferase (AST), alanine aminotransferase (ALT), lactate dehydrogenase (LDH), and alkaline phosphatase (AP), was estimated in blood plasma as well. The indices were determined in blood plasma by colorimetric methods according to the manufacturer's protocol using reagent kits (BioMaxima, Lublin, Poland) and a random access biochemical analyzer Metrolab 2300 GL (Metrolab SA, Buenos Aires, Argentine). The analysis procedures were verified with the use of multiparametric control plasma (BioCal) as well as control plasma with a normal level (BioNorm) and a high level (BioPath) of indices (BioMaxima, Lublin, Poland; Hydrex Diagnostics, Warsaw, Poland). The concentrations of immunoglobulins $\mathrm{G}, \mathrm{M}$, and $\mathrm{A}$ in the plasma of the birds were quantified by an enzyme linked immunosorbent assay (ELISA) procedure on a BioTek ELx808 Absorbance Microplate Reader (BioTek, Winooski, VT, USA). The protocol was adapted from a commercially developed assay (Bethyl Laboratories Inc., Montgomery, TX, USA).

Statistical analysis. Each cage was used as a statistical unit. The data obtained were analyzed by the ANOVA method using one-way analysis of variance and two-way ANOVA ( 2 types of inulin extracts and 3 inulin extracts levels) $(\alpha=95 ; \mathrm{p} \leq 0.05)$ and calculating the mean values for the treatments $(\overline{\mathrm{x}})$ and the standard error of the mean with Statistica software (version 10; StatSoft, Tulsa, OK, USA). 
Tab. 1. Dietary ingredients and the nutrient content of the experimental diets (as-fed basis)

\begin{tabular}{|c|c|c|c|c|c|c|c|c|c|c|c|c|c|c|}
\hline \multirow{4}{*}{ Ingredients } & \multicolumn{14}{|c|}{ Diets } \\
\hline & \multirow{3}{*}{$\begin{array}{c}\text { Control } \\
0\end{array}$} & \multicolumn{6}{|c|}{ Starter (0 to 21 days) } & \multicolumn{7}{|c|}{ Grower (22 to 42 days) } \\
\hline & & \multicolumn{3}{|c|}{ SI } & \multicolumn{3}{|c|}{ LCI } & \multirow{2}{*}{$\begin{array}{c}\text { Control } \\
0\end{array}$} & \multicolumn{3}{|c|}{ SI } & \multicolumn{3}{|c|}{ LCI } \\
\hline & & I & II & III & IV & v & VI & & I & II & III & IV & v & VI \\
\hline \multicolumn{15}{|c|}{ Diet composition, \% } \\
\hline Maize & 39.00 & 39.00 & 39.00 & 39.00 & 39.00 & 39.00 & 39.00 & 31.00 & 31.00 & 31.00 & 31.00 & 31.00 & 31.00 & 31.00 \\
\hline Wheat & 20.32 & 20.32 & 20.32 & 20.32 & 20.32 & 20.32 & 20.32 & 30.10 & 30.10 & 30.10 & 30.10 & 30.10 & 30.10 & 30.10 \\
\hline Soybean meal, $\mathbf{4 6} \%$ crude protein & 33.29 & 33.29 & 33.29 & 33.29 & 33.29 & 33.29 & 33.29 & 29.67 & 29.67 & 29.67 & 29.67 & 29.67 & 29.67 & 29.67 \\
\hline Soybean oil & 2.40 & 2.40 & 2.40 & 2.40 & 2.40 & 2.40 & 2.40 & 4.30 & 4.30 & 4.30 & 4.30 & 4.30 & 4.30 & 4.30 \\
\hline Corn starch & 1.00 & 0.80 & 0.60 & 0.40 & 0.80 & 0.60 & 0.40 & 1.00 & 0.80 & 0.60 & 0.40 & 0.80 & 0.60 & 0.40 \\
\hline Water extract of inulin & - & 0.20 & 0.40 & 0.60 & - & - & - & - & 0.20 & 0.40 & 0.60 & - & - & - \\
\hline Water-alcohol extract of inulin & - & - & - & - & 0.20 & 0.40 & 0.60 & - & - & - & - & 0.20 & 0.40 & 0.60 \\
\hline Monocalcium phosphate & 1.30 & 1.30 & 1.30 & 1.30 & 1.30 & 1.30 & 1.30 & 1.40 & 1.40 & 1.40 & 1.40 & 1.40 & 1.40 & 1.40 \\
\hline Limestone & 0.76 & 0.76 & 0.76 & 0.76 & 0.76 & 0.76 & 0.76 & 0.60 & 0.60 & 0.60 & 0.60 & 0.60 & 0.60 & 0.60 \\
\hline $\mathrm{NaHCO}_{3}$ & 0.12 & 0.12 & 0.12 & 0.12 & 0.12 & 0.12 & 0.12 & 0.12 & 0.12 & 0.12 & 0.12 & 0.12 & 0.12 & 0.12 \\
\hline $\mathrm{NaCl}$ & 0.27 & 0.27 & 0.27 & 0.27 & 0.27 & 0.27 & 0.27 & 0.27 & 0.27 & 0.27 & 0.27 & 0.27 & 0.27 & 0.27 \\
\hline Lysine $\mathrm{HCl}$ & 0.21 & 0.21 & 0.21 & 0.21 & 0.21 & 0.21 & 0.21 & 0.20 & 0.20 & 0.20 & 0.20 & 0.20 & 0.20 & 0.20 \\
\hline DL-methionine & 0.28 & 0.28 & 0.28 & 0.28 & 0.28 & 0.28 & 0.28 & 0.27 & 0.27 & 0.27 & 0.27 & 0.27 & 0.27 & 0.27 \\
\hline L-threonine & 0.05 & 0.05 & 0.05 & 0.05 & 0.05 & 0.05 & 0.05 & 0.07 & 0.07 & 0.07 & 0.07 & 0.07 & 0.07 & 0.07 \\
\hline Vitamin-mineral premix ${ }^{1}$ & 1.00 & 1.00 & 1.00 & 1.00 & 1.00 & 1.00 & 1.00 & 1.00 & 1.00 & 1.00 & 1.00 & 1.00 & 1.00 & 1.00 \\
\hline \multicolumn{15}{|c|}{ Chemical composition $(\mathrm{g} / \mathrm{kg})$} \\
\hline MEn (MJ/kg) & 12.6 & 12.6 & 12.6 & 12.6 & 12.6 & 12.6 & 12.6 & 13.1 & 13.1 & 13.1 & 13.1 & 13.1 & 13.1 & 13.1 \\
\hline Crude protein & 215.5 & 215.3 & 215.2 & 215.1 & 215.4 & 215.2 & 215.1 & 202.5 & 201.8 & 200.9 & 200.8 & 200.5 & 200.8 & 200.2 \\
\hline Ether extract & 61.4 & 61.4 & 61.3 & 61.3 & 61.4 & 61.2 & 61.2 & 86.4 & 86.4 & 86.2 & 86.1 & 86.5 & 86.4 & 86.2 \\
\hline Crude fiber & 25.4 & 25.2 & 25.2 & 25.1 & 25.2 & 25.2 & 25.1 & 31.4 & 31.2 & 31.2 & 31.1 & 31.2 & 31.1 & 31.0 \\
\hline Crude ash & 55.9 & 55.8 & 55.8 & 55.7 & 55.8 & 55.8 & 55.7 & 55.6 & 55.6 & 55.4 & 55.3 & 55.5 & 55.6 & 55.4 \\
\hline Lys & 13.1 & 13.1 & 13.1 & 13.0 & 13.1 & 13.1 & 13.0 & 12.3 & 12.3 & 12.2 & 12.2 & 12.3 & 12.1 & 12.2 \\
\hline Met + Cys & 8.32 & 8.32 & 8.31 & 8.31 & 8.32 & 8.30 & 8.31 & 8.12 & 8.12 & 8.11 & 8.11 & 8.12 & 8.12 & 8.11 \\
\hline $\mathrm{Ca}$ & 10.15 & 10.14 & 10.12 & 10.11 & 10.13 & 10.12 & 10.10 & 9.43 & 9.42 & 9.39 & 9.40 & 9.41 & 9.38 & 9.37 \\
\hline $\mathbf{P}$ & 6.76 & 6.74 & 6.74 & 6.73 & 6.74 & 6.74 & 6.73 & 6.54 & 6.53 & 6.52 & 6.51 & 6.52 & 6.50 & 6.51 \\
\hline $\mathrm{Na}$ & 1.68 & 1.68 & 1.68 & 1.68 & 1.68 & 1.68 & 1.68 & 1.65 & 1.65 & 1.65 & 1.65 & 1.65 & 1.65 & 1.65 \\
\hline
\end{tabular}

Explanations: ${ }^{1}$ added minerals and vitamins per kg of starter diet: $\mathrm{Mn}, 70 \mathrm{mg}$; I, $1 \mathrm{mg}$; Fe, $70 \mathrm{mg}$; Zn, $60 \mathrm{mg}$; $\mathrm{Se}, 0.3 \mathrm{mg}$; Cu, 8 mg; vitamin $\mathrm{A}, 12.000 \mathrm{IU}$; vitamin $\mathrm{D}_{3}, 2.500 \mathrm{UI}$; vitamin $\mathrm{E}, 25 \mathrm{mg}$; vitamin $\mathrm{K}_{3}, 3 \mathrm{mg}$; vitamin $\mathrm{B}_{1}, 2 \mathrm{mg}$; vitamin $\mathrm{B}_{2}, 6 \mathrm{mg}$; vitamin $\mathrm{B}_{6}$, $5 \mathrm{mg}$; vitamin $\mathrm{B}_{12}, 0.02 \mathrm{mg}$; biotin, $0.2 \mathrm{mg}$; folic acid, $2 \mathrm{mg}$; nicotic acid, $30 \mathrm{mg}$; pantothenic acid, $15 \mathrm{mg}$; choline chloride, $700 \mathrm{mg}$. Added minerals and vitamins per kg of grower diet: Mn, $60 \mathrm{mg}$; I, $0.7 \mathrm{mg}$; Fe, $50 \mathrm{mg}$; Zn, $50 \mathrm{mg}$; Se, $0.2 \mathrm{mg}$; Cu, 7 mg; vitamin A, $10.000 \mathrm{IU}$; vitamin $\mathrm{D}_{3}, 2.000 \mathrm{UI}$; vitamin $\mathrm{E}, 25 \mathrm{mg}$; vitamin $\mathrm{K}_{3}, 2 \mathrm{mg}$; vitamin $\mathrm{B}_{1}, 2 \mathrm{mg}$; vitamin $\mathrm{B}_{2}$, 4 mg; vitamin $\mathrm{B}_{6}$, 4 mg; vitamin $\mathrm{B}_{12}, 0.02 \mathrm{mg}$; biotin, $0.2 \mathrm{mg}$; folic acid, $1 \mathrm{mg}$; nicotic acid, $25 \mathrm{mg}$; pantothenic acid, $15 \mathrm{mg}$; choline chloride, $300 \mathrm{mg}$.

\section{Results and discussion}

The effects of the inulin treatments on the blood of the broiler chickens are presented in Tables 2-4. The addition of inulin had a significant $(p \leq 0.05)$ impact on the blood parameters analyzed, especially on the protein and lipid profile. The degree of polymerization of inulin and its level in the diet significantly affected the content of glucose and uric acid and creatinine levels in the blood plasma of 21-day-old chickens. The other biochemical indices were not affected by the experimental factors. Some differences $(p \leq 0.05)$ between the experimental groups were found in total cholesterol and its HDL fraction content as well as in the activity of ALT and LDH.
On the other hand, in the blood plasma of 42-day-old chickens, the type of inulin (SI vs. LCI) influenced creatinine, total cholesterol and triacylglycerol contents and the AST activity. The level of inulin in the diet significantly affected the LDL fraction of cholesterol, and hence the share of HDL in the total cholesterol content, and the activity of AST. The interaction of the two experimental factors (DP $\times \mathrm{L}$ ) had an influence on lipid parameters and AST activity in the finishing broiler chickens. The blood proteinogram was also significantly changed by the experimental factors (Tab. 4). The addition of different types (SI vs. LCI) and levels $(0.2,0.4$, and 0.6) of inulin to the diet and the interaction of these factors affected the total protein level and the content of 
Tab. 2. Effect of the dietary level of two types of inulin (SI vs. LCI) on blood metabolic parameters of 21-day-old broiler chickens

\begin{tabular}{|c|c|c|c|c|c|c|c|c|c|c|c|c|}
\hline \multirow{3}{*}{$\begin{array}{c}\text { Groups } \\
\text { Inulin share, \% }\end{array}$} & \multirow{3}{*}{$\begin{array}{c}\text { Control } \\
1 \\
0\end{array}$} & \multicolumn{3}{|c|}{ SI } & \multicolumn{3}{|c|}{ LCI } & \multirow{3}{*}{$\begin{array}{l}\text { Pooled } \\
\text { SEM }\end{array}$} & \multirow{3}{*}{ Treatment } & \multirow{2}{*}{\multicolumn{3}{|c|}{ Effect of ${ }^{c}$}} \\
\hline & & II & III & IV & v & VI & VII & & & & & \\
\hline & & 0.2 & 0.4 & 0.6 & 0.2 & 0.4 & 0.6 & & & DP & $\mathbf{L}$ & $D P \times L$ \\
\hline Glucose, $\mathrm{mmol} \mathrm{I}^{-1}$ & $13.85^{\mathrm{ab}}$ & $14.36^{\mathrm{b}}$ & $13.74^{\mathrm{ab}}$ & $12.62^{b}$ & $13.85^{a b}$ & $12.35^{\mathrm{b}}$ & $12.26^{b}$ & 0.207 & * & * & * & * \\
\hline Uric acid, $\mu \mathrm{mol} \mathrm{l^{-1 }}$ & 0.491 & 0.406 & 0.358 & 0.348 & 0.419 & 0.360 & 0.266 & 0.016 & ns & * & * & * \\
\hline UREA, mmol l-1 & 0.83 & 0.81 & 0.79 & 0.79 & 0.82 & 0.78 & 0.79 & 0.013 & ns & ns & ns & ns \\
\hline Creatinine, $\mu \mathrm{mol} \mathrm{I}^{-1}$ & $30.06^{a}$ & $26.51^{b}$ & $28.22^{\mathrm{a}}$ & $27.13^{b}$ & $28.06^{\mathrm{ab}}$ & $29.16^{\mathrm{a}}$ & $27.55^{b}$ & 0.254 & * & * & * & * \\
\hline Bilirubin, $\mu \mathrm{mol} \mathrm{I}^{-1}$ & 4.18 & 4.32 & 4.37 & 4.42 & 4.29 & 4.40 & 4.33 & 0.071 & ns & ns & ns & ns \\
\hline Total cholesterol, mmol l-1 & $3.80^{\mathrm{a}}$ & $3.73^{\mathrm{a}}$ & $3.73^{\mathrm{a}}$ & $3.70^{\mathrm{ab}}$ & $3.80^{\mathrm{a}}$ & $3.53^{\mathrm{ab}}$ & $3.11^{\mathrm{b}}$ & 0.058 & * & ns & ns & ns \\
\hline HDL-Chol, mmol l-1 & $2.67^{\mathrm{ab}}$ & $2.25^{\mathrm{ab}}$ & $2.39^{\mathrm{ab}}$ & $2.36^{\mathrm{ab}}$ & $2.68^{\mathrm{b}}$ & $2.20^{\mathrm{ab}}$ & $1.77^{\mathrm{b}}$ & 0.064 & * & ns & ns & ns \\
\hline Triacylglicerols, mmol I-1 & 0.41 & 0.39 & 0.36 & 0.42 & 0.41 & 0.40 & 0.38 & 0.010 & ns & ns & ns & ns \\
\hline LDL-Chol, mmol I-1 & 0.93 & 1.30 & 1.17 & 1.16 & 0.93 & 1.14 & 1.16 & 0.062 & ns & ns & ns & ns \\
\hline CHOL/HDL & 1.42 & 1.66 & 1.56 & 1.58 & 1.42 & 1.61 & 1.78 & 0.042 & ns & ns & ns & ns \\
\hline$\% \mathrm{HDL}$ & 71.16 & 60.38 & 64.42 & 64.13 & 71.16 & 62.40 & 56.97 & 1.55 & ns & ns & ns & ns \\
\hline AST, $\mathrm{U} \mathrm{I}^{-1}$ & 210.5 & 156.6 & 178.1 & 175.1 & 210.5 & 201.4 & 152.9 & 5.75 & ns & ns & ns & ns \\
\hline ALT, $\mathrm{U} \mathrm{I}^{-1}$ & $23.51^{\mathrm{ab}}$ & $26.82^{\mathrm{ab}}$ & $17.41^{\mathrm{b}}$ & $27.50^{\mathrm{a}}$ & $23.51^{\mathrm{ab}}$ & $22.10^{\mathrm{ab}}$ & $18.33^{a b}$ & 0.93 & * & ns & ns & ns \\
\hline$A P, \mathrm{U} \mathrm{I}^{-1}$ & 2124 & 2002 & 1857 & 2103 & 2116 & 1987 & 2030 & 35.48 & ns & ns & ns & ns \\
\hline LDH, $\mathbf{U}^{-1}$ & $1337^{\mathrm{ab}}$ & $1406^{a b}$ & $1520^{\mathrm{ab}}$ & $1281^{b}$ & $1341^{\mathrm{ab}}$ & $1495^{\mathrm{ab}}$ & $1586^{\mathrm{a}}$ & 25.62 & * & ns & ns & ns \\
\hline
\end{tabular}

Explanations: ${ }^{\mathrm{a}, \mathrm{b}}$ - values in the rows with different letters differ significantly at $\mathrm{p} \leq 0.05$; $^{\mathrm{c}}$ effect of experimental factors: DP - degree of polymerization, $\mathrm{L}$ - level of inulin in the diet

Tab. 3. Effect of the dietary level of two types of inulin (SI vs. LCI) on blood metabolic parameters of 42-day-old broiler chickens

\begin{tabular}{|c|c|c|c|c|c|c|c|c|c|c|c|c|}
\hline \multirow{3}{*}{$\begin{array}{c}\text { Groups } \\
\text { Inulin share, \% }\end{array}$} & \multirow{3}{*}{$\begin{array}{c}\text { Control } \\
\\
0\end{array}$} & \multicolumn{3}{|c|}{ SI } & \multicolumn{3}{|c|}{ LCI } & \multirow{3}{*}{$\begin{array}{l}\text { Pooled } \\
\text { SEM }\end{array}$} & \multirow{3}{*}{ Treatment } & \multirow{2}{*}{\multicolumn{3}{|c|}{ Effect of ${ }^{d}$}} \\
\hline & & II & III & IV & v & VI & VII & & & & & \\
\hline & & 0.2 & 0.4 & 0.6 & 0.2 & 0.4 & 0.6 & & & DP & $\mathbf{L}$ & $D P \times L$ \\
\hline Glucose, $\mathrm{mmol} \mathrm{I}^{-1}$ & 11.64 & 12.16 & 12.01 & 11.90 & 12.21 & 12.29 & 12.27 & 0.113 & ns & ns & ns & ns \\
\hline Uric acid, $\mu \mathrm{mol} \mathrm{I}^{-1}$ & 290.9 & 281.1 & 269.8 & 301.7 & 266.5 & 259.4 & 267.7 & 0.013 & ns & ns & ns & ns \\
\hline Urea, mmol l-1 & 0.78 & 0.77 & 0.77 & 0.75 & 0.78 & 0.75 & 0.76 & 0.012 & ns & ns & ns & ns \\
\hline Creatinine, $\mu \mathrm{mol} \mathrm{I-1}$ & $32.81^{\mathrm{ab}}$ & $33.15^{\mathrm{ab}}$ & $36.70^{\mathrm{a}}$ & $33.48^{\mathrm{ab}}$ & $32.01^{\mathrm{b}}$ & $31.81^{b}$ & $32.89^{\mathrm{ab}}$ & 0.410 & * & * & ns & ns \\
\hline Bilirubin, $\mu \mathrm{mol} \mathrm{I}^{-1}$ & 5.21 & 4.56 & 4.71 & 4.65 & 4.87 & 4.40 & 4.52 & 0.086 & ns & ns & ns & ns \\
\hline Total cholesterol, mmol l-1 & 3.16 & 3.52 & 3.71 & 3.68 & 3.32 & 3.23 & 3.40 & 0.061 & ns & * & ns & * \\
\hline HDL-Chol, mmol I-1 & $2.06^{\mathrm{ab}}$ & $2.34^{\mathrm{ab}}$ & $2.52^{\mathrm{a}}$ & $2.22^{\mathrm{ab}}$ & $2.40^{\mathrm{ab}}$ & $1.95^{\mathrm{ab}}$ & $1.71^{\mathrm{b}}$ & 0.068 & * & ns & ns & ns \\
\hline Triacylglycerols, mmol I-1 & $0.40^{\mathrm{ab}}$ & $0.34^{b}$ & $0.44^{\mathrm{a}}$ & $0.35^{\mathrm{ab}}$ & $0.31^{b}$ & $0.15^{c}$ & $0.38^{\mathrm{ab}}$ & 0.014 & * & * & ns & * \\
\hline LDL-Chol, mmol l-1 & $0.91^{b}$ & $1.02^{\mathrm{ab}}$ & $0.99^{\mathrm{ab}}$ & $1.29^{\mathrm{ab}}$ & $0.83^{b}$ & $1.21^{\mathrm{ab}}$ & $1.51^{\mathrm{a}}$ & 0.056 & * & ns & * & * \\
\hline CHOL/HDL & $1.54^{\mathrm{ab}}$ & $1.50^{\mathrm{b}}$ & $1.48^{b}$ & $1.66^{\mathrm{ab}}$ & $1.41^{\mathrm{ab}}$ & $1.66^{\mathrm{ab}}$ & $2.00^{\mathrm{a}}$ & 0.043 & * & ns & * & ns \\
\hline$\% \mathrm{HDL}$ & $62.08^{\mathrm{ab}}$ & $66.26^{\mathrm{a}}$ & $67.89^{\mathrm{a}}$ & $60.81^{a b}$ & $72.10^{\mathrm{a}}$ & $60.85^{\mathrm{ab}}$ & $50.70^{\mathrm{b}}$ & 1.503 & * & ns & * & ns \\
\hline AST, $\mathrm{U} \mathrm{I}^{-1}$ & $181.2^{c}$ & $223.5^{\mathrm{ab}}$ & $233.4^{\mathrm{ab}}$ & $243.4^{\mathrm{a}}$ & $219.7^{\mathrm{ab}}$ & $208.0^{b}$ & $234.6^{\mathrm{ab}}$ & 3.684 & * & * & * & * \\
\hline ALT, $\mathrm{U}^{-1}$ & 20.30 & 22.11 & 22.60 & 20.61 & 21.91 & 19.32 & 22.53 & 0.381 & ns & ns & ns & ns \\
\hline$A P, U^{-1}$ & 1773 & 1801 & 1706 & 1659 & 1685 & 1816 & 1715 & 27.94 & ns & ns & ns & ns \\
\hline LDH, $\mathrm{U} \mathrm{I}^{-1}$ & 1561 & 1457 & 1432 & 1621 & 1568 & 1460 & 1552 & 17.89 & ns & ns & ns & ns \\
\hline
\end{tabular}

Explanations: ${ }^{a, b, c}$ - values in the rows with different letters differ significantly at $\mathrm{p} \leq 0.05$; ${ }^{\mathrm{d}}$ effect of experimental factors: DP degree of polymerization, $\mathrm{L}-$ level of inulin in the diet

albumins and globulins. The concentration of IgG class immunoglobulins was not affected by the treatment, but significant differences were found between the other classes of immunoglobulins analyzed, A and $\mathrm{M}$.

The objective of rational poultry nutrition is to achieve maximum production, while maintaining the birds in good health through beneficial effects of feed ingredients on the digestive tract, metabolism, and stimulation of the immune system. This is particularly important in breeding animals of high production potential. An important factor in the efficacy of feed additives in animal nutrition is the course of metabolic processes, which is manifested in, among other things, changes in the values of biochemical and hematological markers (30). 
Tab. 4. Effect of the dietary level of two types of inulin (SI vs. LCI) on blood plasma proteins of broiler chickens

\begin{tabular}{|c|c|c|c|c|c|c|c|c|c|c|c|c|c|}
\hline \multirow{3}{*}{\begin{tabular}{|c|} 
Groups \\
Inulin share, \% \\
\end{tabular}} & \multirow{3}{*}{$\begin{array}{l}\text { Day } \\
\text { of life }\end{array}$} & \multirow{3}{*}{$\begin{array}{c}\text { Control } \\
1 \\
0\end{array}$} & \multicolumn{3}{|c|}{ SI } & \multicolumn{3}{|c|}{ LCI } & \multirow{3}{*}{$\begin{array}{l}\text { Pooled } \\
\text { SEM }\end{array}$} & \multirow{3}{*}{ Treatment } & \multirow{2}{*}{\multicolumn{3}{|c|}{ Effect of ${ }^{d}$}} \\
\hline & & & II & III & IV & v & VI & VII & & & & & \\
\hline & & & 0.2 & 0.4 & 0.6 & 0.2 & 0.4 & 0.6 & & & DP & $\mathbf{L}$ & $D P \times L$ \\
\hline \multirow{2}{*}{ Total protein, $\mathrm{g} \mathrm{l}^{-1}$} & 21d & $29.53^{b}$ & $28.49^{b}$ & $28.03^{b}$ & $30.06^{b}$ & $29.53^{b}$ & $34.71^{\mathrm{a}}$ & $29.13^{b}$ & 0.324 & * & * & * & * \\
\hline & $42 d$ & $30.16^{b}$ & $27.22^{c}$ & $31.71^{\mathrm{ab}}$ & $27.94^{c}$ & $32.52^{\mathrm{a}}$ & $30.31^{\mathrm{ab}}$ & $32.12^{\mathrm{a}}$ & 0.308 & * & * & ns & * \\
\hline \multirow{2}{*}{ Albumin } & 21d & $17.24^{b}$ & $15.25^{c}$ & $15.9^{\mathrm{bc}}$ & $16.11^{\mathrm{bc}}$ & $17.23^{b}$ & $19.88^{\mathrm{a}}$ & $15.32^{c}$ & 0.248 & * & * & * & * \\
\hline & $42 d$ & $15.39 \mathrm{~b}$ & $14.73^{b}$ & $16.1^{b}$ & $12.02^{c}$ & $18.11^{a}$ & $17.54^{\mathrm{ab}}$ & $16.91^{\mathrm{ab}}$ & 0.295 & * & * & * & * \\
\hline \multirow{2}{*}{ Globulin } & 21d & $10.28^{b}$ & $11.28^{\mathrm{ab}}$ & $11.13^{a b}$ & $12.94^{\mathrm{a}}$ & $11.38^{\mathrm{ab}}$ & $11.85^{a}$ & $12.01^{a}$ & 0.151 & * & * & * & * \\
\hline & $42 d$ & $12.5 g^{a b}$ & $11.47^{\mathrm{b}}$ & $13.64^{\mathrm{ab}}$ & $13.91^{\mathrm{a}}$ & $13.61^{\mathrm{ab}}$ & $12.68^{\mathrm{ab}}$ & $13.70^{\mathrm{a}}$ & 0.173 & * & ns & * & * \\
\hline \multirow{2}{*}{$\lg \mathrm{G}, \mathrm{mg} \mathrm{ml}^{-1}$} & 21d & 2.15 & 2.73 & 2.81 & 2.81 & 2.35 & 2.37 & 2.45 & 0.074 & ns & * & ns & ns \\
\hline & $42 d$ & 3.74 & 3.91 & 4.07 & 4.18 & 3.95 & 4.09 & 4.16 & 0.100 & ns & ns & ns & ns \\
\hline \multirow{2}{*}{$\lg M, \mathrm{mg} \mathrm{ml}^{-1}$} & 21d & 0.26 & 0.29 & 0.33 & 0.35 & 0.29 & 0.33 & 0.31 & 0.013 & ns & ns & ns & ns \\
\hline & $42 d$ & $0.72^{\mathrm{b}}$ & $0.88^{\mathrm{ab}}$ & $0.97^{a}$ & $0.93^{\mathrm{a}}$ & $0.85^{\mathrm{ab}}$ & $0.83^{\mathrm{ab}}$ & $0.75^{b}$ & 0.018 & * & * & * & * \\
\hline \multirow{2}{*}{$\lg A, \mathrm{mg} \mathrm{ml}^{-1}$} & 21d & $0.06^{b}$ & $0.07^{a b}$ & $0.07^{\mathrm{ab}}$ & $0.08^{\mathrm{a}}$ & $0.06^{b}$ & $0.06^{b}$ & $0.06^{b}$ & 0.002 & * & * & ns & ns \\
\hline & $42 d$ & $0.24^{b}$ & $0.26^{\mathrm{ab}}$ & $0.28^{\mathrm{ab}}$ & $0.29^{a}$ & $0.18^{c}$ & $0.19^{c}$ & $0.22^{\mathrm{bc}}$ & 0.006 & * & * & ns & ns \\
\hline
\end{tabular}

Explanations: as in Tab. 3

Blood analyses, widely used in large domestic animal medicine, are not commonly performed in avian diagnostics, because no physiological reference values are available (28). Furthermore, the considerable individual differences in the biochemical indices of birds are the main reason for the wide physiological ranges specified for chickens (17).

There are many published studies on humans and animals concerning the direct and/or indirect effects of dietary prebiotic supplements, including inulin, on the structure and functioning of various systems and organs in the organism. In studies on farm animals, the addition of prebiotics was found to stimulate the performance of animals, stabilize the microbiome of the digestive tract, and improve animal health status (10, $13,15,24,54)$. On the other hand, other authors did not find such an impact $(4,11)$. Some studies proved that prebiotics have growth-promoting effects similar to antibiotic treatments (21). Positive changes in digestive enzymes, gut morphology, and the immune system were found in birds given prebiotic-supplemented feed $(12,52)$. However, there are many factors to be considered when supplementing prebiotics in animal feed (54), which include the type of diet (i.e., the content of non-digestible oligosaccharides), the type and inclusion level of the supplements, animal characteristics (species, age, stage of production), and the hygiene status of the farm (46). The optimal dose of prebiotics exerting a growth-promoting effect is not easy to define. Biggs et al. (5) proved that feeding a higher level $(0.8 \%)$ of inulin and short-chain fructo-oligosaccharides depressed growth performance, the digestibility of amino acids, and metabolizable energy in birds. However, there are studies in which even a higher dose was supplemented (1\%) (24). Moreover, as reported by Ten Bruggencate et al. (44), the rapid fermentation of prebiotics leading to high concentrations of organic acids impaired the barrier function, which reduced the ability of rats to resist salmonella infection. Besides, the influence

can be modulated also by the interaction between the prebiotic and the sex of birds. Yusrizal and Chen (55) observed that the body weight and feed conversion ratio (FCR) of female birds were improved by $10 \%$ and $9 \%$, respectively, upon oligofructose treatment, but no such effects were observed in males. The results of our study also proved that the type of inulin (SI vs. LCI) and its level $(0.2,0.4$, or 0.6$)$ influenced the blood indices of broiler chickens.

Lipid metabolites are strongly associated with energy metabolism and reflect its fluctuation during the growth period (28). Numerous studies on humans and animals showed that dietary fructans have hypolipidemic properties manifested by a lowered plasma total cholesterol and triacylglycerol content $(18,50)$. There are several hypotheses that explain these mechanisms. According to Delzenne et al. (6), these properties may result from a reduced absorption of nutrients, an enhanced excretion of bile acids, or improved propionic acid production by microorganisms in the gastrointestinal tract. Synthesis of bile acids from cholesterol in the liver is the most important way of cholesterol excretion (51). Prebiotics and probiotics can modulate cholesterol concentrations by increasing the activity of lactic acid bacteria, which produce enzymes that disintegrate bile salts and deconjugate them, as well as SCFA that lower $\mathrm{pH}$ in the intestinal tract (2). At a low $\mathrm{pH}$, the solvability of nonconjugate bile acids is lowered, and they are absorbed less from the intestine and are excreted more in the feces. To reestablish the hepatic cycle of bile acids, the liver converts more cholesterol into tissue, and in consequence the concentration of CHOL in blood is reduced (34). On the other hand, propionic acid is an inhibitor of the hydroxymethylglutaryl-CoA reductase enzyme necessary for cholesterol synthesis, which reduces endogenous cholesterol biosynthesis in the liver (48). The triacylglycerol-lowering action of oligofructose is due to the reduction in de novo fatty acid synthesis in the liver (48). In the present study, we noted a downward trend 
in the total cholesterol, LDL-Chol, and triacylglycerol content in the blood plasma of broiler chickens fed a diet supplemented with inulin, as well as a noticeably higher share of the HDL cholesterol fraction, compared with that in the control group (Tab. 3). This confirms findings reported by other authors $(2,9,36,45,53)$. The results obtained in chickens by Rebole et al. (29) and Velasco et al. (45) proved that inulin modifies the hepatic metabolism of lipids.

Since proteins play crucial roles in transport, enzymatic, regulatory, and immune functions, their level in blood plasma is a good indicator of the health and nutritional status of the organism. The supplementation of inulin also had significant impact on the protein profile in chickens' blood (Tab. 4). Increased total protein and globulin levels were detected in the blood plasma of the inulin-treated broiler chickens. A similar tendency was found by Mátéová et al. (23) and Al-Kassie et al. (1). Higher serum globulin is an indicator of a better immune response and a source of antibody production (39). As far as the humoral defense system is concerned, one might expect an increase in humoral systemic response induced by inulin supplementation. Prebiotics, including inulin, can directly and indirectly affect some of the mechanisms of resistance in animals, with positive effects in terms of their better productivity and health. Although the effect of prebiotics, including inulin, on the synthesis and activity of sIgA antibodies in the gastrointestinal tract has been confirmed (57), their impact on systemic antibody concentrations requires further investigation. According to Seifert and Waltz (40) and Tazoe et al. (43), the application of prebiotics caused increased production of short-chain fatty acids (SCFA) in the bloodstream, which can interact with the immune cells by binding to $G$ protein-coupled receptors, such as GPR41 and GPR43, located in polymorphonuclear cells and peripheral blood mononuclear cells. Butyrate, one of SCFA, can suppress lymphocyte proliferation, inhibit cytokine production of Th1 lymphocytes, induce T-lymphocyte apoptosis, and increase production of IL-10.

The effects of oligosaccharides on the microbial population and immune system of the gastrointestinal tract of chickens were described in several works $(15,42)$. Our studies confirmed the impact $(p \leq 0.05)$ of the type of inulin on the IgM and IgA concentration. However, compared to the control birds, there was a clear dosedependent tendency for the $\operatorname{IgG}$ concentration in the inulin-treated groups to increase, irrespective of the inulin type. There was an increase in the concentration of all immunoglobulin classes, especially visible during the initial rearing period, which confirms the results reported by other authors $(15,38)$.

In birds, the content of uric acid, a major final product of nitrogen metabolism and an endogenous antioxidant in plasma, is strongly influenced by such factors as age, sex, and nutrition, whereas the content of urea and ammonia are only slightly modified by these factors (39). In this study, no effect of the inulin treatments on the level of blood urea nitrogen was noted. Nevertheless, a reduced level of uric acid was detected in the groups receiving inulin, especially in the long-chain inulin (LCI) groups. The decrease in the uric acid concentration in blood plasma may suggest greater utilization of absorbed protein or a decrease in endogenous protein turnover in broiler chickens (39). As inulin is fermented in the large intestine and stimulates the growth of lactic acid bacteria, mainly from the genus Bifidobacterium, a significant increase in the production of short-chain fatty acids (SCFA) is observed. The consequence of the increased production of SCFA is a decrease in the $\mathrm{pH}$ of the intestinal content. In an acidic intestinal environment, not only the proliferation of pathogenic microorganisms is reduced, but also the solubility of micro- and macronutrients as well as the pool of ionized components and their absorption increase. Reduction in the concentration of non-protein nitrogen in blood induced by supplemental dietary probiotics or a modification of native microbiota has been reported in poultry $(20,25)$.

The liver serves a major function in the organism's detoxification process. The measurement of the activity of hepatic enzymes provides efficient indicators of the health safety of inulin supplementation in broiler diets. The activity of AST in the finishing broiler chickens was higher than in the control group. The statistical analysis also confirmed that the AST activity was affected by the type and level of dietary inulin. However, the activities of all enzymes analyzed were within the normal range (39) in the inulin-treated groups, which confirmed the normal liver function. Similar tendencies in enzyme activity were demonstrated by Yalçinkaya et al. (53).

The results of the study show that the two types of inulin differing in the degree of polymerization (DP) (standard inulin from chicory root with $\mathrm{DP} \geq 10$ (SI) vs. long-chain inulin (LCI) of DP $\geq 23$ ) can modulate the metabolic profile in broiler chickens. The degree of polymerization (DP) largely determines the site of fructan fermentation in the gastrointestinal tract (16, 49). Fructans with a low polymerization degree undergo relatively fast microbial fermentation, while long-chain fructans are more resistant to fermentation and undergo the process only in the end parts of the gastrointestinal tract (37). Although fructans with varied degrees of polymerization stimulated the growth and activity of various Bifidobacterium and Lactobacillus species present in the entire gastrointestinal tract (27), short-chain fructans were fermented by a greater number of Bifidobacterium species (35). The different fermentation place in the gastrointestinal tract, dependent on the polymerization degree, and the influence of inulin on the intestinal microbiota can have varying effects on the fluctuations of blood indices. However, the mechanisms through which these effects develop are still unclear.

In the present study, it seems that inulin with the higher polymerization degree (LCI; DP $\geq 23$ ) provided better results in terms of the blood metabolic profile throughout the broiler fattening period. However, the impact of this factor is not explicit. The addition of the inulin extract at an amount of 4-6 g per $\mathrm{kg}$ of mixture is recommended, but further experiments are recommended. 


\section{References}

1. Al-Kassie G. A. M., Al-Jumaa Y. M. F., Jameel Y. J.: Effect of probiotic (Aspergillus niger) and prebiotic (Taraxacum officinale) on blood picture and biochemical properties of broiler chicks. Int. J. Poult. Sci. 2008, 7, 1182-1184.

2. Ashayerizadeh A., Dabiri N., Ashayerizadeh O., Mirzadeh K. H., Roshankefr H., Mamooee M.: Effect of dietary antibiotic, probiotic and prebiotic as growth promoters, on growth performance, carcass characteristics and hematological indices of broiler chickens. Pak. J. Biol. Sci. 2009, 12, 52-57.

3. Aviagen 2014. Ross broiler management handbook. Retrieved on 10 April 2016 from http://en.aviagen.com/assets/Tech_Center/Ross_Broiler/Ross-BroilerHandbook-2014i-EN.pdf

4. Bachanek I., Barszcz M., Taciak M., Tuśnio A., Skomiat J.: Microbial activity in the large intestine of chicks fed diets with different types and levels of inulin. Ann. Anim. Sci. 2016, 16, 4, 1141-1152.

5. Biggs P., Parsons C., Fahey G. C.: The effect of oligosaccharides on growth performance, nutrient utilization and caecal microbes in young chicks. Poultry Sci. 2007, 86, 2327-2336.

6. Delzenne N. M., Williams C. M.: Prebiotics and lipid metabolism. Curr. Opin. Lipidol. 2002, 13, 61-67.

7. Friedewald W. T., Levy R. I., Fredickson D. S.: Estimation of the concentration of low-density lipoprotein cholesterol in plasma, without use of the preparative ultracentrifuge. Clin. Chem. 1972, 18, 499-502.

8. Ganguly S.: Supplementation of prebiotics, probiotics and acids on immunity in poultry feed: a brief review. World Poultry Sci. J. 2013, 69, 639-648.

9. Ghasemi H. A., Kasani N., Taherpour K.: Effects of black cumin seed (Nigella sativa L.), a probiotic, a prebiotic and a symbiotic on growth performance, immune response and blood characteristics of male broilers. Livestock Sci. 2014 $164,128-134$

10. Grela E. R., Sobolewska S., Kowalczuk-Vasilev E., Krasucki W.: Effect of dietary inulin source on piglet performance, immunoglobulin concentration, and plasma lipid profile. Bull. Vet. Inst. Pulawy 2014, 58, 453-458.

11. Hedemann M. S., Knudsen K. E. B.: Dried chicory root has minor effects on the digestibility of nutrients and the composition of the microflora at the terminal ileum and in faeces of growing pigs. Livestock Sci. 2010, 134, 53-55.

12. Huang R. L., Deng Z. Y., Yang C., Yin Y. L., Xie M. Y., Wu G. Y., Li T. J., Li-Li-Li, Tang Z. R., Kang P., Hou Z. P., Deng D., Xiang H., Feng Kong X., Guo Y. M.: Dietary oligochitosan supplementation enhances immune status of broilers. J. Sci. Food Agric. 2007, 87, 153-159.

13. Janardhana V., Broadway M. M., Bruce M. P., Lowenthal J. W., Geier M. S., Hughes R. J., Bean A. G. D.: Prebiotics modulate immune responses in the gut-associated lymphoid tissue of chickens. J. Nutr. 2009, 139, 1404-1409.

14. Kelly G.: Inulin-type prebiotics - a review: part 1. Altern. Med. Rev. 2008, 13, 315-329.

15. Kim G.-B., Seo Y. M., Kim C. H., Paik I. K.: Effect of dietary prebiotic supplementation on the performance, intestinal microflora, and immune response of broilers. Poultry Sci. 2011, 90, 75-82.

16. Kleessen B., Hartman L., Balut M.: Oligofructose and long-chain inulin: influence on the gut microbial ecology of rats associated with a human faecal flora. Br. J. Nutr. 2001, 2, 291-300

17. Krasnodębska-Depta A., Koncicki A.: Physiological values of selected serum biochemical indices in broiler chickens. Med. Weter. 2000, 56, 456-460.

18. Krejpcio Z., Wójciak R. W., Staniek H., Wiśniewska J.: Effect of dietary fructans and chromium (III) supplementation on apparent fat digestibility and blood lipid indices in rat. Acta Sci. Pol. Technol. Aliment. 2009, 8, 85-92.

19. Letexier D., Diraison F., Beylot M.: Addition of inulin to a high carbohydrate diet reduces hepatic lipogenesis and plasma triacylglycerol concentration in humans. Am. J. Clin. Nutr. 2003, 77, 559-564.

20. Li W. F., Rajput I. R., Xu X., Li Y. L., Lei J., Huang Q., Wang M. Q.: Effects of probiotic (Bacillus subtilis) on laying performance, blood biochemical properties and intestinal microflora of Shaoxing duck. Int. J. Poult. Sci. 2011, 108, 583-589.

21. Li X., Liu L. Q., Xu C. L.: Effects of supplementation of fructo-oligosaccharide and or Bacillus subtilis to diets on performance and intestinal microflora in broilers. Archiv für Tierzucht 2008, 51, 64-70.

22. Madrigal L., Sangronis E.: Inulin and derivates as key ingredients in functional foods. Arch. Latinoam. Nutr. 2007, 57, 387-396.

23. Mátéová S., Šăly J., Tuèková M., KoščováJ., Nemcová R., Gaálová M., Baranová D. Effect of probiotics, prebiotics and herb oil on performance and metabolic parameters of broiler chickens. Med. Weter. 2008, 64, 294-297.

24. Nabizadeh A.: The effect of inulin on broiler chicken intestinal microflora, gut morphology and performance. J. Anim. Feed Sci. 2012, 21, 725-734.

25. Pan D., Yu Z.: Intestinal microbiome of poultry and its interaction with host and diet. Gut Microbes 2014, 5, 108-119.

26. Park S. O., Park B. S.: Effect of dietary microencapsulated-inulin on carcass characteristics and growth performance in broiler chickens. J. Anim. Vet. Adv. $2011,10,1342-1349$

27. Patterson J. K., Yasuda K., Welch R. M., Miller D. D., Lei X. G.: Supplemental dietary inulin of variable chain lengths alters intestinal bacterial populations in young pigs. J. Nutr. 2010, 140, 2158-2161.

28. Piotrowska A., Burlikowska K., Szymeczko R.: Changes in Blood Chemistry in Broiler Chickens during the Fattening Period. Folia biológica (Kraków) 2011, 59, 3-4, 183-187

29. Rebole A., Ortiz L. T., Rodriguez M. L., Alzueta C., Trevino J., Velasco S.: Effects of inulin and enzyme complex, individually or in combination, on growth performance, intestinal microflora, cecal fermentation characteristics, and jejunal histomorphology in broiler chickens fed a wheat- and barley-based diet. Poultry Sci 2010, 89, 276-286.

30. Reece W. O., Erickson H. H., Goff J. P., Uemura E. E.: Dukes' physiology of domestic animals, $13^{\text {th }}$ edition. Wiley Blackwell, New York, NY, USA 2015.

31. Rehman H., Hellweg P., Taras D., ZentekJ.: Effect of dietary inulin on the intestinal short chain fatty acids and microbial ecology in broiler chickens as revealed by denaturing gradient gel electrophoresis. Poultry Sci. 2008, 87, 783-789.

32. Rehman H. C., Rosenkranz C., Bölem J., Zentek J.: Dietary inulin affects the morphology but not sodium dependent glucose and glutamine transport in the jejunum of broilers. Poultry Sci. 2007, 86, 118-122.

33. Ronkart S. N., Blecker C. S., Fourmanoir H., Fougnies C., Deroanne C., Herck $J$. V., Paquot M.: Isolation and identification of inulooligosaccharides resulting from inulin hydrolysis. Anal. Chim. Acta 2007, 604, 81-87.

34. Ros E.: Intestinal absorption of triglyceride and cholesterol. Dietary and pharmacological inhibition to reduce cardiovascular risk. Atherosclerosis 2000, 151, 357-379.

35. Rossi M., Corradini C., Amaretti A., Nicolini M., Pompei A., Zanoni S., Matteuzzi D.: Fermentation of fructooligosaccharides and inulin by Bifidobacteria: a comparative study of pure and fecal cultures. Appl. Environ. Microbiol. 2005, 71, 6150-6158.

36. Safaa H. M., Jiménez-Moreno E., Frikha M., Mateos G. G.: Plasma lipid metabolites and liver lipid components in broilers at 21 days of age in response to dietary different fiber sources. Egyptian J. Anim. Prod. 2014, 51, 115-127.

37. Samolinska W., Grela E. R.: Comparative effects of inulin with different polymerization degrees on growth performance, blood trace minerals, and erythrocyte indices in growing-finishing pigs. Biol. Trace Elem. Res. 2017, 176, 130-142.

38. Sang-Oh P., Byung-Sung P.: Effect of dietary microencapsulated-inulin on carcass characteristics and growth performance in broiler chickens. J. Anim. Vet. Adv. 2011, 10, 1342-1349

39. Scanes C. G. (ed.): Sturkie's avian physiology, $6^{\text {th }}$ edition. Academic Press, London, UK 2015.

40. Seifert S., Watzl B.: Inulin and oligofructose: review of experimental data on immune modulation. J. Nutr. 2007, 137 (Suppl. 11), S2563-S2567.

41. Sevane N., Bialade F., Velasco S., Rebolé A., Rodríguez M. L., Ortiz L. T., Cañón J., Dunner $S$.: Dietary inulin supplementation modifies significantly the liver transcriptomic profile of broiler chickens. PLoS One 2014, 9, 1-9.

42. Sugiharto S.: Role of nutraceuticals in gut health and growth performance of poultry. J. Saudi Soc. Agric. Sci. 2014, doi:10.1016/j.jssas.2014.06.001

43. Tazoe H., Otomo Y., Kaji I., Tanaka R., Karaki S. I., Kuwahara A.: Roles of shortchain fatty acids receptors, GPR41 and GPR43 on colonic functions. J. Physiol. Pharmacol. 2008, 59, Suppl. 2, 251-262.

44. Ten Bruggencate S. J., Bovee-Oudenhoven I. M., Lettink-Wissink M. L., Van der Meer R.: Dietary fructo-oligosaccharides increase intestinal permeability in rats. J. Nutr. 2005, 135, 837-842.

45. Velasco S., Ortiz L. T., Alzueta C., Rebole' A., Trevino J., Rodríguez M. L.: Effect of inulin supplementation and dietary fat source on performance, blood serum metabolites, liver lipids, abdominal fat deposition, and tissue fatty acid composition in broiler chickens. Poult. Sci. 2010, 89, 1651-1662.

46. Verdonk J. M. A. J., Shim S. B., Van Leeuwen P., Verstegen M. W. A.: Application of inulin-type fructans in animal feed and pet food. Br. J. Nutr. 2005, 93, S125-S138.

47. Vergauwen R., Van Laere A., Van Den Ende W.: Properties of fructan: fructan 1 -fructosyltransferases from chicory and globe thistle, two Asteracean plants storing greatly different types of inulin. Plant. Physiol. 2003, 133, 391-401.

48. Walker D. K., Gilliland S. E.: Relationships among bile tolerance, bile salt deconjugation and assimilation of cholesterol by Lactobacillus acidophilus. J. Dairy Sci. 1993, 76, 956-961.

49. Wiele T. van de, Boon N., Possemiers S., Jacobs H., Verstraete W.: Inulin-type fructans of longer degree of polymerization exert more pronounced in vitro prebiotic effects. J. Appl. Microbiol. 2007, 102, 452-460.

50. Williams M., Jackson K. G.: Inulin and oligofructose: effects on lipid metabolism from human studies. Br. J. Nutr. 2002, 87, 261-264.

51. Wilson T. A., Nicolosi R. J., Rogers E. J., Sacchiero R., Goldberg D. J.: Studies of cholesterol and bile acid metabolism, and early atherogenesis in hamsters fed GT16-239 , a novel bile acid sequestrant (BAS). Atherosclerosis 1998, 140, 315-324.

52. Xu Z. R., Hu C. H., Xia M. S., Zhan X. A., Wang M. Q.: Effects of dietary fructooligosaccharide on digestive enzyme activities, intestinal microflora and morphology of male broilers. Poult. Sci. 2003, 82, 1030-1036

53. Yalçinkaya I., Çinar M., Yildirim E., Erat S., Başalan M., Güngör T.: The effect of prebiotic and organic zinc alone and in combination in broiler diets on the performance and some blood parameters. Ital. J. Anim. Sci. 2012, 11, 3, 298-302.

54. Yang Y., Iji P. A., Choct M.: Dietary modulation of gut microflora in broiler chickens: A review of the role of six kinds of alternatives to in-feed antibiotics. World's Poult. Sci. J. 2009, 65, 97-114.

55. Yusrizal Y., Chen T. C.: Effect of adding chicory fructans in feed on broiler growth performance, serum cholesterol and intestinal length. Int. J. Poult. Sci. 2003, 2, 214-219.

56. Zalecenia żywieniowe i wartość pokarmowa pasz. Normy żywienia drobiu. Praca zbiorowa pod redakcją Stefanii Smulikowskiej i Andrzeja Rutkowskiego. Instytut Fizjologii i Żywienia Zwierząt im. Jana Kielanowskiego PAN, Jabłonna. Polski Oddział Światowego Towarzystwa Wiedzy Drobiarskiej (WPSA), 2005.

57. Zhang B., Guo Y., Wang Z.: The modulating effect of $\beta$-1,3/1,6-glucan supplementation in the diet on performance and immunological responses of broiler chickens. Asian-Aust. J. Anim. Sci. 2008, 21, 237-244.

Corresponding author: Dr inż. Edyta Kowalczuk-Vasilev, Akademicka 13, 20-950 Lublin, Poland; e-mail: edyta.kowalczuk@up.lublin.pl 